\title{
A IMPORTÂNCIA DO JOGO E DA BRINCADEIRA NA EDUCAÇÃO INFANTIL
}

Fernanda Cargnin Gonçalves ${ }^{1}$

Durante sua curta vida, Vygotsky abordou diferentes temas em suas inúmeras obras, e alguns deles foram aprofundados por seus colaboradores, como o russo Leontiev. Uma das temáticas abordadas por estes dois autores é o papel do brinquedo no desenvolvimento infantil, da qual podemos retirar diferentes aspectos. Contudo, o presente trabalho se limita às seguintes dimensões: a busca de satisfação dos desejos da criança através do brinquedo; os jogos de papéis e os jogos com regras explícitas; e a importância do brincar na fusão entre significado e visão durante o período infantil.

No período pré-escolar da vida da criança, ela desenvolve a consciência do mundo objetivo, e como este é amplamente "guiada" pelos adultos, ela se esforça para se comportar da mesma forma que eles. Segundo Leontiev (1992), a criança passa por uma fase na qual quer realizar sozinhas as ações que as motivam, além disso, busca satisfazer seus desejos imediatamente, crianças pequenas não conseguem planejar ações para um tempo posterior ao que estão vivendo, como percebemos na teoria de Vygotsky (1991).

Quando a criança percebe que existem desejos os quais não consegue realizá-los de imediato ou esquecê-los, como, por exemplo, ser sua própria professora, ela recorre à brincadeira:

No início da idade pré-escolar, quando surgem os desejos que não podem ser imediatamente satisfeitos ou esquecidos, e permanece ainda a característica do estágio precedente de uma tendência para a satisfação imediata desses desejos, o comportamento da criança muda. Para resolver essa tensão, a criança em idade pré-escolar envolve-se num mundo ilusório e imaginário onde os desejos não realizáveis podem ser realizados, e esse mundo é o que chamamos de brinquedo. (Vygotsky, 1991, p. 106)

Entretanto, isto não significa que a criança sempre irá brincar quando não consegue satisfazer um desejo, ela precisa estar motivada para realizar tal ação, e só assim criará uma situação imaginária.

Ao estudarmos Leontiev percebemos que ele traz as diferenças e semelhanças entre jogos de papéis e jogos com regras explícitas. Os jogos de papéis, também

\footnotetext{
11 Aluna da oitava fase do curso de graduação em Pedagogia - habilitação em Educação Infantil, da Universidade Federal de Santa Catarina.
} 
chamados de jogos lúdicos, jogos de enredo ou "teatrinho", aparecem principalmente nas crianças pré-escolares, aqui os pequenos assumem uma função social humana, já que eles possuem a necessidade de compreender o mundo que os cerca, ou seja, o mundo dos adultos.

As brincadeiras neste período representam algo que as crianças vêem na realidade, como por exemplo, o brincar de "lojinha", elas assumem papéis que existem neste ambiente, como o do vendedor, do caixa e do cliente, mas estes personagens não representam uma pessoa específica, ela "assume certa função social generalizada do adulto..." (Leontiev, 1992 p.130). Neste tipo de jogo, apesar de não serem explícitas, existem regras, as crianças agem de acordo com a regra latente da função social que estão brincando, mesmo que não tenham consciência disto. Um exemplo é a brincadeira de "mamãe e filhinho", a criança que ficou com o papel do filhinho sabe que não pode mandar na mamãe, e a que é o filhinho subentende que precisa dar ordens e tomar algumas atitudes, como dar comida, fazer dormir, etc.

No decorrer do desenvolvimento infantil surgem outros tipos de jogos, são os jogos com regras explícitas: “... os jogos de enredo com uma situação imaginária são transformados em jogos com regras nos quais a situação imaginária e o papel estão contidos em forma latente".(Leontiev, 1992 p. 133) Desta maneira, percebemos que apesar da mudança em relação às regras, a imaginação continua a existir no jogo. Esta divisão entre formas de jogos não impede que crianças de diferentes idades participem deles, e para facilitar o ingresso das crianças com menos de três anos nos jogos com regras, já que não conseguem cumpri-las, se insere um simbolismo à brincadeira.

A terceira dimensão tratada aqui, abrange a importância do brinquedo na separação entre os objetos que a criança vê o significado que possuem. Vygostky (1991) afirma que crianças muito pequenas não conseguem separar o campo visual externo do campo cognitivo, elas agem de acordo com o que os objetos pedem. Elas não conseguem, por exemplo, dizer que um cachorro é um gato, se o que está vendo é um cachorro. É só a partir da atividade lúdica que esta separação começará acontecer: "A criança vê um objeto, mas age de maneira diferente em relação àquilo que ela vê. Assim, é alcançada uma condição em que a criança começa a agir independentemente daquilo que ela vê". (Vygotsky, 1991).

A partir da brincadeira, a criança começa a agir a partir das suas idéias, e não só da realidade. Mas esta mudança não acontece repentinamente, por um período nem todos os objetos podem ser qualquer coisa, precisa existir alguma relação entre o real e o 
imaginário. È possível que uma criança diga que um skate é um carro, porque o primeiro pode ser usado como o segundo de alguma maneira, mas uma caneta, por exemplo, não pode ser transformada em um carro, já que não é possível usá-la de maneira que represente o referido objeto.

O brinquedo e a brincadeira são tratados por muitas pessoas como apenas uma atividade da criança sem importância para o seu desenvolvimento. Contudo, percebemos nas obras de Vygotsky e Leontiev que eles são essenciais na aprendizagem de diferentes habilidades. A criança utiliza o jogo para saciar seus desejos, usando para isso a imaginação, não ficando apenas na esfera do mundo objetivo. Ela também avança na medida que usa a brincadeira para perfurar a barreira que existe entre significado e visão, utilizando mais do seu cognitivo. Através dos diferentes tipos de jogos, como os "de papéis" e os que possuem regras explícitas as crianças passam a compreender o mundo social em que vivem e que estão inseridas. Entretanto, aqueles que brincam não possuem consciência de todos estes avanços, eles estão preocupados apenas em brincar, porque isto faz bem para eles. Cabe então à família e à Educação Infantil proporcionarem brincadeiras às crianças não pensando apenas no seu desenvolvimento, mas também no seu bem estar físico, social e cognitivo.

\section{Bibliografia}

LEONTIEV, Alexis N. Os princípios psicológicos da brincadeira pré-escolar. In: VIGOTSKII, L.S. Linguagem, desenvolvimento e aprendizagem. São Paulo: ÍconeEDUSP, 1998. Tradução de Maria da Penha Villalobos.

REGO, Teresa Cristina. Vygotsky: uma perspectiva histórico-cultural da educação. Petrópolis, RJ: Vozes, 1995.

VYGOTSKY, Lev Semenovich. O papel do brinquedo no desenvolvimento. In: A formação social da mente. São Paulo: Martins Fontes, 1991, 